\title{
Efektifitas Pengelolaan Alokasi Dana Desa Dalam Meningkatkan Pembangunan Fisik Di Desa Kampo-Kampo Kecamatan Binongko Kabupaten Wakatobi
}

\author{
La Sumianto ${ }^{1}$ \\ ${ }^{1}$ Universitas Muhammadiyah Buton
}

\begin{abstract}
Abstrak: Penelitian ini bertujuan Untuk mengetahui Efekfitas Pengelolaan Alokasi Dana Desa Dalam Meningkatkan Pembangunan Fisik Di Desa Kampo-Kampo Kecamatan Binongko Kabupaten wakatobi. Penelitian ini menggunakan metode penelitian deskripsi kualitatif. Dalam pengolahan anggaran baik alokasi Dana desa maupunj Dana Desa, masih banyak yang harus diperbaiki, hal ini dapat dilihat masih banyak anggaran yang belum terserap dalam kegiatan pembangunan fisik sehingga anggaran tiap tahun masih banyak sisa penganggarannya. Untuk itu diharapkan pelaoran keuangan disusun secara bertahap disesuaikan dengan tahapan, baik disepakati dalam program musyawarah pembangunan desa maupun pencairan dimana pelaporan berupa realisasi dari dana yang diterima. Hasil penelitian menunjukan bahwa pembangunan fisik di Desa Kampo-Kampo masih lambat diterapkan dengan cukup melihat realisasi pendapatan dan pengeluaran yang masih tersisa untuk mengusulkan rencana pembangunan yang lainnya. Saran penelitian ini mengungkapkan bahwa informasi yang dilakukan oleh pemerintah desa kepada masyarakat adalah kunci utama sehingga masyarakat dapat memahaminya dengan baik tentang rencana pembangunan serta Peningkatkan Sumber Daya, meskipun dengan kekuranga tingkat pendidikan bias dilakukan dengan pelatihan-pelatihan untuk meningkatkan ataupun dalam pemahaman tentang masalah tugas dan fungsi, serta pelatihannya berkaitan dengan dana desa untuk pengetahuan yang lebih dalam lagi.
\end{abstract}

Kata Kunci: Efektifitas, Dana Desa, Pembangunan

Abstract: This study aims to determine the Effectiveness of Management of Village Fund Allocation in Increasing Physical Development in Kampo-Kampo Village, Binongko District, Wakatobi Regency. This study uses a qualitative description research method. In processing good budgets for village fund allocations to the Village Fund, there is still much that needs to be improved, this can be seen that there are still many budgets that have not yet been absorbed in physical development activities so that the annual budget still has a lot of budget left over. For this reason, it is expected that financial reports will be arranged in stages according to the stages, both agreed upon in the village development consultative program and disbursement where reporting is in the form of realization of funds received. The results of the study show that physical development in Kampo-Kampo Village is still slow to implement, with enough to see the realization of the remaining income and expenditure to propose other development plans. The suggestion of this study reveals that information carried out by the village government to the community is the main key so that the community can understand it well about development plans as well as Enhancing Resources, even though the level of education can be done with training to improve or to understand tasks and functions, and training related to village funds for deeper knowledge.

Keywords: Effectiveness, Village Funds, Development 


\section{Pendahuluan}

Pemerintah Indonesia saat ini berupaya meningkatkan pelaksanaan Pembangunan Nasional agar laju pembangunan daerah serta laju pembangunan desa dan kota semakin seimbang dan serasi. Namun pembangunan Nasional pada pelaksanaannya masih dihadapkan dengan masalah pokok pembangunan seperti ketimpangan pembangunan antara desa dan kota di Indonesia.

Ketimpangan pembangunan terjadi karena banyak faktor yang mempengaruhinya sehingga pembangunan di Indonesia tidak merata sehingga berdampak pada tingginya kemiskinan diIndonesia. Terkait dengan masalah kemiskinan, menurut data BPS jumlah penduduk miskin pada September 2014 mencapai 27,73 juta $(10,96 \%$ total penduduk). Sebanyak 17,37 juta berada di desa dan 10,36 juta di kota. Menanggapi permasalahan tersebut, strategi pemerintah untuk mengatasi ketimpangan pembangunan yaitu dengan melaksanakan pembangunan nasional yang menaruh perhatian besar terhadap pembangunan desa.

Dengan pemberian otonomi desa yang seluasluasnya berarti pemberian kewenangan kepada desa untuk mengolah dan memanfaatkan sumberdaya daerah secara optimal. Meskipuan titik berat otonomi diletakan pada tingkat Kabupaten/Kota, namun secara hakikat sebenarnya kemandirian tersebut harus dimulai dari level pemerintahan ditingkat yang paling bawah, yaitu Desa. Selama ini, Pembangunan desa masih banyak bergantung dari pendapatan asli desa dan swadaya masyarakat, dan Alokasi Dana Desa yang diberikan oleh pemerintah Kabupaten/Kota melalui APBD Kabupaten/Kota tersebut sehingga dirasa masih kurang efektif dalam melakukan pembangunan baik dari segi infrastruktur ataupun sumberdaya manusianya.

Peraturan Pemerintah Nomor 47 Tahun 2015 tentang Perubahan atas Peraturan Pemerintah No 43 Tahun 2014 Tentang Peraturan Pelaksana UndangUndang No 6 tahun 2014 tentang Desa terdapat dialamnya beberapa kewenangan sesuai dengan PP tersebut Desa pasal 34 didalamnya tersirat bahwa dana Dana desa itu berasal dari APBN sedangkan untuk Dana ADD, Dana ini dalam bentuk Alokasi dana Desa. Sedangkan dalam Peraturan Pemerintah Nomor 72 Tahun 2005 tentang Desa pasal 68 ayat 1 poin c, menyebutkan bahwa bagian dari dana perimbangan pusat dan daerah yang diterima oleh kabupaten/kota untuk desa, paling sedikit $10 \%$ secara proposional pembagiannya untuk setiap desa, Dana ini dalam bentuk Alokasi dana Desa atau sering disebut sebagai ADD.

Peraturan Pemerintah Nomor 22 tahun 2015 merupakan pedoman bagi aparatur pemerintahan desa untuk meningkatkan bahkan membuat desa yang kekurangan infrastruktur dan saran kebutuhan pelayanan umum lainnya bisa 
terpenuhi, dimana banyak sekali desa saat ini masih dalam kategori desa tertinggal. Karena dengan adanya Kebijakan Pemerintah Tentang Dana Desa tersebut desa yang masih masuk dalam kategori Desa tertinggal bisa secara bertahap berkembang menjadi Desa Maju/ Mandiri. Alolasi Dana Desa (ADD) adalah dana yang dialokasikan oleh Pemerintah Kabupaten untuk desa, yang bersumber dari bagian dana perimbangan keuangan pusat dan daerah yang diterima oleh Kabupaten. Pemerintahan pedesaan adalah merupakan pemerintah yang paling bawah yang langsung bersentuhan dengan masyarakat, sehingga tingkat kepercayaan masyarakat atas pengelolaan pemerintah desa sangat dibutuhkan. Selain dari masyarakat juga dibutuhkan kepercayaan dari tingkatan pemerintahan yang lebih tinggi lagi yaitu perintah daerah dan pusat, karena dari pemerintahlah sebagaian dana di salurkan kedesa, salah satunya adalah Alokasi Dana desa (ADD).

Sumber keuangan dari Alokasi Dana Desa adalah merupakan dana dari perimbangan daerah yang cukup signifikan jumlahnya, sehingga perlu adanya penanganan yang khusus baik dalam pengelolaan maupun pencatatannya. Dengan pengelolaan yang baik diharapkan dana yang berasal dari Alokasi dana Desa bisa menunjang program desa sehingga tujuan pemerintah tercapai.

Alokasi dana desa dan Dana desa yang diterima Desa Kampo-Kampo Desa Kampo-kampo Kecamatan Binongko 2 tahun terakhir ini cukup beragam yaitu dalam tabel 1 :

Tabel 1. Alokasi Dana Desa 2 Tahun Terakhir

\begin{tabular}{|c|c|c|c|}
\hline \multirow{2}{*}{ No } & \multirow{2}{*}{ Tahun } & \multicolumn{2}{|c|}{ Dana Yang Diterima } \\
\cline { 3 - 4 } & & ADD & DD \\
\hline 1 & 2017 & 608.599 .000 & 793.674 .000 \\
\hline 2 & 2018 & 638.605 .000 & 769.674 .000 \\
\hline
\end{tabular}

Sumber : Data Desa Kampo-Kampo

Alokasi Dana Desa adalah dana yang cukup signifikan bagi Desa untuk menunjang program-program Desa terutama pengadaan infrastruktur Desa. Pengelolaan tersebut baik dari anggaran sampai realisasi harus melibatkan tokohtokoh masyarakat dan aparat Pemerintah Daerah. Kendala-kendala yang dihadapi oleh Pemerintah Daerah baik Pemerintah desa dan Pemerintah Kecamatan adalah kurangnya pengendalian terhadap pengelolaan Dana yang berasal dari Alokasi dana Desa, Hal ini disebabkan karena minimnya sumber daya yang ada dan kontrol dari Pemerintah dan Masyarakat.

\section{Metode Penelitian}

Jenis penelitian yang digunakan dalam penelitian ini adalah Kualitatfif Deskriptif. Menurut Sugiyono (2008:15) bahwa penelitian kualitatif deskriptif adalah metode penelititan yang berlandaskan pada filsafat postpositivismeyang biasanya digunakan untuk meneliti pada kondisi objektif yang alamiah dimana peneliti berperan sebagai 
instrumen kunci. Penelititan kualitatif digunakan untuk mendapatkan data yang mendalam, suatu data yang mengandung makna. Jenis penelitian tentang bagaimana peneliti melakukan penelitian berdasarkan fakta-fakta yang nampak sebagaimana adanya yang berada dilapangan.

\section{Pembahasan}

\section{Pengelolahan Dana Desa di Desa} Kampo-kampo

Penyusunan APBDesa Tahun

Anggaran 2017 didasarkan pada

Peraturan Bupati Wakatobi Nomor 08 Tahun 2017 tentang Pedoman Pengelolaan Keuangan Desa Tahun Anggaran 2017. Penetapan APBDesa Perubahan Tahun Anggaran 2017 dengan Peraturan Desa Kampo-Kampo Nomor 08 Tahun 2017. Dalam mengoptimalkan pengelolaan keuangan desa, kebijakan anggaran APBDesa Tahun 2017 dilaksanakan dengan prinsip Partisifasi Masyarakat, Transfaransi dan Akuntabilitas Anggaran, Disiplin Anggaran, Keadilan Anggaran, Efisiensi dan Efektivitas Anggaran,serta Taat Azas APBDesa.

Alokasi Dana Desa adalah merupakan dana perimbangan pemerintah pusat dan daerah yang dimaksudkan untuk membiayai program pemerintahan desa dalam melaksanakan kegiatan pemerintahan dan pemberdayaan masyarakat. ADD bersumber dari anggaran pendapatan dan belanja daerah tahun berjalan.
Mekanisme penyaluran ADD adalah sebagai berikut:

1. Pelaksana pengelola Keuangan Desa (PPKD) mengajukan S kepada Kades

2. Kades menandatangi SPP kemudian diberikan kepada Bendahara Desa

3. Bendahara mengirimkan SPP kepada Camat untuk dimintakan rekomendasi pencairan di BPR-BKK

4. Dana yang cair diberikan kepada Bendahara Desa untuk dibukukan dan dicatat dalam BKU kemudian diserahkan kepada pelaksana pengelola keuangan desa (PPKD) disertai bukti penerimaan

5. PPKD mempertanggungjawabkan kegunaannya.

Penggunaan ADD diperuntukkan pengeluaran penyelenggaraan Pemeintah Desa yaitu belanja rutin pemerintah desa, alokasi BPD maksiomal 30\% dari ADD yang diterima. Sedangkan yang $70 \%$ untuk pengeluaran pemberdayaan masyarakat yaitu perbaikan sarana publik atau pembangunan fisik.

\section{Pengelolaan Pendapatan Desa sebagai berikut :}

a. Intensifikasi

Sesuai dengan Peraturan

Pemerintah Nomor 22 Tahun 2015 menyangkut tentang Dana Desa yang berasal dari APBN yang betujuan untuk melakukan pembangunan secara merata di seluru pelosok Desa di Indonesia demi meningkatkan pembangunan Infrastruktur dan kesejahteraan masyarakat Indonesia itu sendiri sedangkan Alokasi dana Desa beraasal 
dari dana peribangan dana pemerintah daerah.

Dana Desa yang merupakan anggaran pemerintah pusat yang akan disalurkan kepada pemerintah desa melalui rekening masing desa.memiliki tahapan penyaluran yang telah diatur dalam pasal 16 Peraturan Pemerintah Nomor 22 Tahun 2016 yang berbunyi : Penyaluran Dana Desa sebagaimana yang di maksud dalam pasal 15 di lakukan secara bertahap pada tahun anggaran berjalan dengan ketentuan :

a. Tahap I pada bulan April sebesar 40\% (Empat puluh per seratus).

b. Tahap II pada bulan Agustus sebesar 40\% (Empat Puluh per seratus).

c. Tahap III pada bulan Oktober sebesar 20\% (Dua Puluh Per Seratus)."

Dalam pasal tersebut berisikan tentang besaran anggaran yang disalurkan ke pemerintahan Desa yang di salurkan secara bertahap dengan rentan waktu yang empat bulan di masing masing tahapannya.

\section{Target dan Realisasi Pendapatan Tahun 2017}

Realisasi pendapatan Desa KampoKampo Pada Tahun Anggaran 2017 mencapai sebesar RP. 1.415.695.900 atau $100 \%$ dari target pendapatan APBDes sebesar Rp.1.415.695.900. Bantuan Keuangan terbesar pendapatan Desa Kampo-Kampo pada Tahun 2017 ini berasal dari APBN/Dana Desa (DD) sebesar Rp.793.674.000,- atau 56,06\% dari total APBDes Tahun 2017.Target dan realisasi pendapatan desa tahun anggaran 2017 sebagaimana dalam tabel 2:

Tabel 2. Target realisasi pendapatan tahun 2017

\begin{tabular}{|c|c|c|c|}
\hline No & Uraian & $\begin{array}{c}\text { Anggaran } \\
\text { (Rp) }\end{array}$ & $\begin{array}{c}\text { Keterangan } \\
\text { *jSumber } \\
\text { Dana }\end{array}$ \\
\hline \multirow[t]{4}{*}{1} & \multicolumn{3}{|c|}{ Pendapatan Transfer } \\
\hline & $\begin{array}{l}\text { - Dana } \\
\text { Desa }\end{array}$ & 793.674 .000 & APBN \\
\hline & $\begin{array}{l}\text { - Alokasi } \\
\text { Dana } \\
\text { Desa }\end{array}$ & 608.599 .000 & APBD \\
\hline & $\begin{array}{l}\text { - Dana } \\
\text { Bagi } \\
\text { Hasil } \\
\text { Pajak } \\
\text { dan } \\
\text { Retribusi }\end{array}$ & 13.422 .900 & BHPR \\
\hline \multicolumn{2}{|c|}{ J U M L A H } & 1.415 .695 .900 & APBDes \\
\hline \multicolumn{2}{|c|}{ S I L P A } & - & APBDes \\
\hline
\end{tabular}

\section{Target dan Realisasi Pendapatan Tahun 2018}

Sedangkan Realisasi pendapatan Desa Kampo-Kampo Pada Tahun Anggaran 2018 mencapai sebesar RP. 845.142 .000 atau $80 \%$ dari target pendapatan APBDes sebesar Rp. 1.422.439.500. Bantuan Keuangan terbesar pendapatan Desa Kampo-Kampo pada Tahun 2018 ini berasal dari APBN/Dana Desa (DD) sebesar Rp.769.965.000,- atau 56,06\% dari total APBDes Tahun 2018.Target dan realisasi pendapatan desa tahun anggaran 2017 sebagaimana dalam tabel 3. : 
Tabel 3. Target dan realisasi pendapatan tahun 2018

\begin{tabular}{|c|c|c|c|}
\hline No & Uraian & $\begin{array}{c}\text { Anggaran } \\
\text { (Rp) }\end{array}$ & $\begin{array}{c}\text { Keterangan } \\
{ }^{*} \text { )Sumber } \\
\text { Dana }\end{array}$ \\
\hline \multirow[t]{4}{*}{$\overline{1}$} & \multicolumn{3}{|c|}{ Pendapatan Transfer } \\
\hline & $\begin{array}{l}\text { - Dana } \\
\text { Desa }\end{array}$ & 769.965 .000 & APBN \\
\hline & $\begin{array}{l}\text { - Alokasi } \\
\text { Dana } \\
\text { Desa }\end{array}$ & 638.605 .000 & APBD \\
\hline & $\begin{array}{l}\text { - Dana } \\
\text { Bagi } \\
\text { Hasil } \\
\text { Pajak } \\
\text { dan } \\
\text { Retribusi }\end{array}$ & 13.865 .500 & BHPR \\
\hline \multicolumn{2}{|c|}{ J U M L A H } & 1.415 .695 .900 & APBDes \\
\hline \multicolumn{2}{|c|}{ S I L P A } & - & APBDes \\
\hline
\end{tabular}

\section{Permasalahan dan Penyelesaian}

Dalam pengelolaan pendapatan desa pada tahun 2017 dan 2018 tidak terdapat permasalahan yang mengakibatkan pengurangan atau penambahan anggaran, semua berjalan sesuai yang direncanakan pada draf APBDes.

Seperti wawancara kepala desa Ahdin, AMF mengatakan bahwa " desa juga beruasaha mencari pendapatan lain sebagai sumber pemasukan desa untuk menantisipasi dana yang dari pemerintah belum kucurkan seperti membuat Peraturan Desa tentang sumbangan masyarakat dalam pengambilan Pasir dan
Batu didesa kami, dan lain halnya . hal ini juga disepakati oleh BPD dalam memutuskan apa yang mejadi syarat pembentukan perdes (Wawancara 12 September 2018)

Namun demikian pemerintahan Desa Kampo-Kampo tetap mengadakan kegiatan antisipasi permasalahan yang akan timbul dan tidak diinginkan. Seperti mencari tambahan tambahan lain untuk meningkatkan anggaran desa dengan tujuan peningkatan potensi desa yang lain sebagai antisipasi jika dana desa dan alokasi dana desa belum ditranfer ke desa tersebut.

\section{b. Ekstensifikasi}

Dalam pengelolahan sumbersumber pendapatan desa tujuanya adalah untuk menambah pendapatan desa yang diperuntukan dalam pembangunan fisik maupun non fisik desa guna menopang pembiyaaan desa, melalui :

1. Pemungutan Retribusi Desa

2. Pengelolahan Badan Usaha Desa(Bumdes)

3. Pengeolahan Pajak Desa

Menurut Ketua BPD bapak La Aena mengatakan penguatan pelaksanaan retribusi desa itu kami sudah lakukan dalam musyawarah desa menetapkan bebrapak hal guna mengantisipasi pemasukan pendapatan desa, yang sala satunya adalah retribusi galian WC, retribusi persampahan, retribusi kawasan pantai dan bebrapa lain perdes yang ditetapkan (wawancara 13 September 2018). 
1. Target dan Realisasi Anggaran Tahun 2018

Serapan atau Realisasi belanja mencapai pendapatan Desa KampoKampo Pada Tahun Anggaran 2018 mencapai sebesar RP. 845.142.000 atau 80\% dari target pendapatan APBDes sebesar Rp. 1.422.439.500. Sebagaimana yang di jelaskan dalam Tabel 5.

Table 5. target dan realisasi anggaran taun 2018

\begin{tabular}{|c|l|r|r|c|}
\hline No & \multicolumn{1}{|c|}{ Pendapatan Desa } & Target (Rp) & \multicolumn{1}{c|}{$\begin{array}{c}\text { Realisasi } \\
\text { (Rp) }\end{array}$} & (\%) \\
\hline 1 & \multicolumn{1}{|c|}{2} & 3 & 4 & 5 \\
\hline 1 & $\begin{array}{l}\text { Bidang Penyelenggaraan } \\
\text { Pemdes }\end{array}$ & 422.570 .000 & 245.304 .000 & 60 \\
\hline 2 & Bidang Pembangunan & 724.442 .000 & 462.998 .500 & 70 \\
\hline 3 & Bidang Pembinaan & 88.113 .000 & 55.688 .000 & 70 \\
\hline 4 & Bidang Pemberdayaan & 194.408 .000 & 88.246 .500 & 40 \\
\hline & \multicolumn{1}{|c|}{ Jumlah } & $\mathbf{1 . 4 2 9 . 5 3 4 . 5 0 0}$ & $\mathbf{8 5 2 . 2 3 7 . 0 0 0}$ & \\
\hline
\end{tabular}

Sumber : Laporan Pertanggung Jawaban Desa Kampo-kampo 2018

\section{Pelaporan ADD Desa Kampo-kampo Kecamatan Binongko}

Pelaporan ADD diperlukan dalam rangka pengendalian dan mengetahui perkembangan proses pengelolaan dan penggunaan ADD. Jenis laporan ADD meliputi:

a. Laporan Berkala

Laporan mengenai pelaksanaan penggunaan dana ADD dibuat secara rutin setiap bulan. Adapun yang dimuat dalam laporan ini adalah realisasi penerimaan ADD, belanja publik ADD dan belanja transfer ADD

b. Laporan Akhir pelaksanaan

Laporan akhir pelaksanaan dari penggunaan alokasi dana desa mencakup perkembangan pelaksanaan dan penyerapan dana, daya serap swadaya masyarakat, tenaga kerja yang diserap dalam proyek ADD, masalah yang dihadapi dan rekomendasi penyelesaian akhir penggunaan ADD.

Laporan ini dilaksanakan melalui jalur struktural yaitu Tim Pelaksana tingkat desa diketahui oleh kepala desa ke Tim Pendamping tingkat kecamatan secara bertahap. Selanjutnya tim pendamping tingkat kecamatan membuat laporan/rekapan dari seluruh laporan tingkat desa di wilayahnya secara bertahap melaporkan kepada Bupati $\mathrm{Cq}$ tim fasilitas tingkat kabuipaten. Sedangkan dalam pelaksanaan dan pelaporan Dana Desa dilakukan pengawasan yang dilakukan oleh Bupati, Inspektorat dan Camat.

Di Desa Kampo-kampo Kecamatan Binongko pelaporan keuangan alokasi dana desa pada masing-masing desa sudah mencapai pada tahap II kecuali untuk desa plana dan kemawi baru untuk tahap I, sedangkan untuk pengawasan 
ADD di Desa Kampo-kampo Kecamatan Binongko desa langsung dengan inspektorat untuk tingkatankecamatan hanya sebagai fasilitator dalam penyelenggaraan ADD agar berjalan sesuai dengan yang diharapkan.

\section{B. Pengelolaan Belanja Desa}

1. Kebijakan Umum Keuangan Desa Sebagaimana Kami Sampaikan Di Atas Bahwa Pengelolaan Keuangan Desa Talah Melalui Beberapa Proses, Hingga Penetapan Dalam Apbdesa, Demikian
Pula Untuk Belanja Desa Juga Melalui Beberapa Proses, Sehingga Dapat Optimal Penggunaanya Dan Dapat Pula Dipertanggungjawabkan Secara Benar.

\section{Target Dan Realisasi Belanja Tahun} 2017

Serapan Atau Realisasi Belanja Mencapai Rp.1.408.600.900,-Atau 99,5\% Dari Total Anggaran Sebesar Rp. 1.415.695.900. Target Dan Realisasi Belanja Apbdesa Kampo-Kampo Tahun Anggaran 2017, Sebagaimana Tabel 6. :

Table 6. target dan realisasi belanja tahhun 2017

\begin{tabular}{|c|c|c|c|c|}
\hline No & Pendapatan Desa & Target (Rp) & Realisasi (Rp) & $\begin{array}{c}\text { Presentase } \\
(\%)\end{array}$ \\
\hline 1 & 2 & 3 & 4 & 5 \\
\hline 1 & $\begin{array}{l}\text { Bidang Penyelenggaraan } \\
\text { Pemdes }\end{array}$ & 433.879 .800 & 433.879 .800 & 100 \\
\hline 2 & Bidang Pembangunan & 482.424 .000 & 482.424 .000 & 100 \\
\hline 3 & Bidang Pembinaan & 116.942 .100 & 116.942 .100 & 100 \\
\hline 4 & Bidang Pemberdayaan & 382.450 .000 & 375.355 .000 & 98,14 \\
\hline & Jumlah & 1.415 .695 .900 & 1.408 .600 .900 & \\
\hline
\end{tabular}

Sumber : Laporan Pertanggung Jawaban Desa Kampo-kampo 2017

Dalam Mengimplementasikan Kebijakan Pemerintah melalui Peraturan Pemerintah Nomor 22 Tahun 2015 selain melakukan perencanaan dan penyelesaian kegiatan perlu juga adanya pertanggung jawaban dari pemerintah desa sebagai bentuk transparansi dan juga bentuk administrasi yang harus dipenuhi oleh pemerintah desa itu sendiri. Dari penelitian terhadap pertanggungjawaban kegaiatan Dana Desa dapat dijabarkan dalam beberapa wawancara yang peneliti lakukan terhadap apartur yang bertanggung jawab didalamnya.

Berdasarkan hasil penelitian setiap tahapan perencanaan, pelaksanaan dan pertanggungjawaban dalam Pengelolaan Alokasi Dana Desa dalam meningkatkan pembangunan fisik Di Desa Kampokampo masih kurang baik. Hal ini dari setiap proses tahapan Pengelolaan Alokasi Dana Desa belum sesuai dengan prinsip pengelolaan dan tujuan Alokasi Dana Desa. Pengelolaan Alokasi Dana Desa dalam meningkatkan pembangunan 
fisik Di Desa Kampo-kampo, dilakukan dengan tiga proses tahapan yaitu perencanaan, pelaksanaan dan pertanggungjawaban masih kurang baik, dimana terkait dengan masih kurangnya sosialisasi dalam setiap musrembang desa sehingga mengakibatkan kurangnya partisipasi masyarakat dikarenakan kurangnya informasi yang diperoleh masyarakat desa, sehingga berdampak pada rendahnya partisipasi dan pengawasan dari masyarakat desa baik secara lembaga ataupun individu dalam setiap tahapan Pengelolaan Alokasi Dana Desa. Kondisi tersebut berdampak pula belum efektifnya pencapaian tujuan Pengelolaan Alokasi Dana Desa dalam meningkatkan pembangunan fisik di Desa Kampo-kampo Kecamatan Binongko Kabupaten Wakatobi.

Selanjutnya, kurangnya partisipasi masyrakat baik secara lembaga maupun individu dalam Pengelolaan Alokasi Dana desa tentu sangat disayangkan. Sebab tujuan Pengelolaan Alokasi Dana Desa yang sekaligus menjadi semangat UU Desa adalah menciptakan masyarakat yang aktif dan mampu menjadi elemen utama dalam merencanakan, melaksanakan dan mengawasi setiap kegiatan pembangunan yang terjadi di desa.

\section{Kesimpulan}

Dalam pelaksanaan ADD dan DD dibutuhkan pengelolaan yang baik, dalam hal ini akan terekam dalam pelaporan keuangan yang diharapkan dapat menunjang dari program-program desa. Hal ini dapat dilihat masih banyaknya anggaran yang belum terserap dalam kegiatan pembanguan fisik sehingga angaran tiap tahun masih banyak sisa penganggaranya. Untuk itu diharapkan pelaporan keuangan disusun secara bertahap disesuaikan dengan tahapan, baik yang disepakati dalam musyawarah pembangunan desa maupun pencairan dimana pelaporan berupa realisasi dari dana yang diterima.

Desa Kampo-kampo Kecamatan Binongko sebagai penerima dana ADD dan DD bertanggungjawab penuh dalam pelaksanaan dan pelaporan keuangan ADD dan pemanfaatannya untuk pembagunan prasarana desa. Pelaporan keuangan ADD di Desa Kampo-kampo Kecamatan Binongko dari tahun ke tahun sudah berjalan sesuai dengan peraturan yang ada tetapi pemanfaatnya belum sepenuhnya dilaksankan. Sedangkan untuk pengawasan pelaksanaan Anggaran tersebut hanya sebatas sebagai fasilitator tetapi tanggungjawab sepenuhnya ada di desa langsung lewat inspektorat dan Badan Permberdayaan Desa.

\section{Daftar Pustaka}

Abdul Wahab, Solichin 2012. Analisis Kebijakan dari Formulasi ke Implementasi Kebijakan Negara. Jakarta : Bumi Aksara. Agustino, Leo 2012. Dasar-dasar Kebijakan Publik. Bandung : Alfabeta.

Asian Development Bank. 1999. Reducing Poverty: Major Findings and 
Implementation, A Report

Based and Consultations in Selected Developing Member Countries of The Asian Development Bank. Asian Development Bank.

Arikunto, Suharsimi. 2006. Prosedur Penelitian Suatu Pendekatan Praktik, Jakarta: Rieneka Cipta

Basri, Yuswar Zainul dan Mulyadi Subri. 2006. Keuangan Negara dan Analisis Kebijakan Utang Luar Negeri, Jakarta: Raja Grafindo

Harbani, Pasolong 2013. Kepemimpinan Birokrasi. Bandung : Alfabeta.

Harsono, Hanifah 2002. Implementasi Kebijakan Politik. Bandung : PT. Mutiara Sumber Widya.

Kuncoro, Murdrajat. 2006. "Ekonomi Pembangunan",Penerbit Salemba Empat,Jakarta.

Miles,Mathew B. Dan A. Michael Huberman. 2007. Analisa Data Kualitatif. Diterjemahkan oleh Tjetjep Rohendi Rohidi. Jakarta : UI Press.

Sadu Wasistono \& Tahir, M. Irwan. 2006. Prospek Pengembangan Desa. Bandung : Fokus Media.

Setiawan, Guntur 2004. Implementasi dalam

Birokrasi
Pembangunan.Bandung

Remaja Rosdakarya Offset.

Sevilla, C, G., Jesus, A., Twila, G., Bella, P., \& Gabriel, G. 2006. Pengantar Metode Penelitian. Jakarta: UI Press

Subarsono, AG 2011. Analisis Kebijakan Publik :Konsep Teori dan Aplikasi. Yogyakarta : Pustaka Pelajar.

Sugiyono. 2008. Metode Penelitian Kualitatif dan R\&D. Bandung : Alfabeta.

Sondang P. Siagian MPA. 2004, Administrasi Pembangunan, (Jakarta: Gunung Agung

Teguh Yuwono, 2001, Manajemen Otonomi Daerah,Pusat Kajian Otonomi Daerah dan Kebijakan Publik (Puskodak), UNDIP, Semarang

Usman, Nurdin. 2002. Konteks Implementasi berbasis Kurikulum. Jakarta :PT. Raja Grafindo Persada.

Widjaja, HAW. 2003. Otonomi Desa. Jakarta : P.T Raja Grafindo Persada.

Wresniwiro, 2012. Membangun Republik Desa. Visimedia. Jakarta 